\title{
Effect of Triclabendazole and Dexamethasone on Ovine Fascioliasis
}

\section{Farouk J. Khali1 ${ }^{1}$; Huda F. Hasan ${ }^{\mathbf{2}}$; Oday K. Luaibi ${ }^{@ 3}$ and Khaled. J. Khalil ${ }^{\mathbf{4}}$}

${ }^{1 .}$ Department of Veterinary Parasitology, ${ }^{2}$ Department of Veterinary Physiology and Pharmacology, ${ }^{3 .}$ Department of Veterinary Internal and Preventive Medicine, College of Veterinary Medicine, University of Baghdad, ${ }^{4}$. Research Center for Cancer and Blood diseases,

AL-Mustanseria University, Iraq

E-mail: dr.odaylauibi@yahoo.com

Accepted on: 1/4/2013

\section{Summary}

Thirty sheep in a flock suffering from fascioliasis were selected for the trial. Clinical findings, hematological, biochemical and fecal investigations were conducted. These animals were equally divided into two groups, the $1^{\text {st }}$ group was given the flukecide triclabendazole alone, at a dose of $12 \mathrm{mg} / \mathrm{kg}$ body weight orally and the $2^{\text {nd }}$ group was given the same dose orally together with dexamethasone at a rate $0.5 \mathrm{mg} / \mathrm{kg}$ body weight $\mathrm{I} / \mathrm{M}$. Results showed that the $2^{\text {nd }}$ group gave the quickest and the best response in the treatment. This could be explained that the use of corticosteroid assisted the triclabendazole in preventing immune damage and fibroplasias inflicted by the liver flukes beside to improvement metabolic actions of the animal.

Keywords: Triclabendazole, Dexamethasone, Fascioliasis, Ovine.

\section{Introduction}

Infection by the liver flukes namely fascioliasis is a worldwide devastating disease that affect a wide variety of hosts particularly, ruminants beside the accidental infection of man (1 and 2). It is regarded as one of the most serious diseases of sheep as the acute stage can cause sudden death while the chronic one cause gradual loss of weight ,anemia, emaciation, loss of wool, hypoproteinemia and other clinical manifestations (3). The disease is very common in Iraq and the two species known, Fasciola hepatica, which is predominant in the northern parts and Fasciola gigantica that increase in incidence in the south beside the middle of the country (4-6). Treatment of the chronic stage which is the highest in incidence (7), flukecides alone may not be sufficient to prevent the progression of liver fibrosis and other clinical manifestation (8).

Corticosteriodes because of their therapeutic benefit to suppress the autoimmune damage inflicted by the parasite and the quickest improvement due to the quick return in the intermediary metabolism in the tissues of infected animals $(8-10)$.

The aim of this study was to evaluate effect of triclabendasake alms and exambintise to treat fascioliasis is oven.

\section{Materials and Methods}

A flock of sheep reared at the south-east of Baghdad suburbs was found to be heavily infected with fascioliasis mostly Fasciola gigantica based on previous identification after postmortem examination and egg measurement, showing clinical signs of chronic fascioliasis. Thirty male sheep aged 2-2.5 years were selected. These animals were equally divided into two groups and put indoor system and were given balanced ruminant ration. The $1^{\text {st }}$ group was given triclabendazole* at a rate of $12 \mathrm{mg} / \mathrm{kg}$ body weight orally while the $2^{\text {nd }}$ group was given the same dose of this flukecide beside the intramuscularly (I/M) injections of dexamethasone $^{* *}$ at a rate of $0.5 \mathrm{mg} / \mathrm{kg}$. The incidences of clinical parameters were recorded and fecal samples were collected for McMaster technique to estimate their e.p.g., weekly (11). Body weights blood were also recorded every week for 4 weeks.

Blood samples were taken from the jugular veins divided into two tubes from each animal weekly one containg Ethylene diamine tetra acetic acid (EDTA) and the tube other for serum enzymes. RBCs counts, $\mathrm{Hb}$ values and PCV \% were estimated according to (12), while absolute eosinophil counts was done according to (13). Mean while, serum glutamic pyruvic transaminase (SGPT), serum glutamic oxaloacetic transaminase (SGOT) 
serum aniline praise transitions (SAPT) and serum lactic dehydrogenase (SLDH) enzyme levels were estimated (14), and total serum bilirubin (15). Statistical analysis was conducted according to Statistical analysis system (SAS) program 2001(16).

*Fascinex, Hoechest, Switzerland

**Cox pharmaceuticals, U.K.

\section{Results and Discussion}

The effect of ovine fascioliasis, as a chronic manifestation is not merely causing anemia, wool loss, gradual deterioration in body condition and the other sufferings but also, the progressive damage of liver parenchyma beside, the fibrosis and even cirrhosis (17-19). After treatment by triclabendazole particularly in the $1^{\text {st }}$ group, the clinical picture was not significantly improved, there was still anemia by reflection of pale mucous membranes, bottle jaw and slower improvement in wool and lesser gain in body weights compared to the second group that was given in addition dexamethasone (Table, 1). Mean while this group showed quickest clinical relief, and significant putting in weight gains $(\mathrm{P}<0.05)$ and this lies in accordance with (10) in sheep and (2) in goats. Concerning the blood picture, there was quick significant hematological improvement reflected by an increase in RBCs counts and hemoglobin values $(\mathrm{P}<0.05)$ particularly in the $2^{\text {nd }}$ group (table,2) compared to the $1^{\text {st }}$ group and this could be attributed to the resumed appetite and whole state of health that may be due to the combined effect of dexamethasone. Meanwhile, eosinophil counts showed significant marked depression $(\mathrm{p}<0.05)$ in the two groups and this could be attributed to disappearance of the flukes and consequously their eggs from the tissues of the hosts beside their metabolites from the blood and this was in accordance with (20 and 21) is goats.

These changes were also, accompanied by significant $(\mathrm{P}<0.05)$ improvement in the liver functions reflected by the significant decrease in the SGOT values in the sera and also the level of SAPT values and also the level of SAPT values $(\mathrm{P}<0.05)$ indicating cellular regeneration by stopping of their ascapage to the circulation and this agree with findings of (21) in goats (21) and in sheep (1). Meanwhile, serum fibrinogen values on contrary exhibited significant increase $(\mathrm{P}<$ $0.05)$ in their means and this indicated that the liver cells resumed their normal production of this important enzyme and this lies in accordance with (21) in goats and (20) in ovine.

It is worthy to mention that bilirubin values of the blood showed better and the quickest significant $(\mathrm{P}<0.05)$ decrease in their means and this could be attributed to the effect of dexamethasone by progressive fibrosis of bile ducts together with triclabendazole that removed the liver flukes and there by relieving the affected animal from jaundice occurred due to obstruction of bile ducts and this lies in agreement with (20). It is worthy to mention that a significant $(\mathrm{P}<$ $0.05)$ increase in glucose level in the $2^{\text {nd }}$ group at the $2^{\text {nd }}$ week post treatment and this could be attributed to the gluconeogenic effect of dexamethasone on the intermediary metabolism which could assist in supplying energy necessary to reactivate tissues and their regeneration (22 and 23).

There was not significant $(\mathrm{P}<0.05)$ changes in cholesterol and SGPT levels through the period of experiment (Table, 2) the egg group showed no count from the $1^{\text {st }}$ week post treatment and this lies in agreement with (20 and 21) in each. It could be concluded that the combined therapeutic effect of triclabendazole together with dexamethasone is beneficial as the latter decrease the progressive fibroplasia and suppressing the auto-immune reaction that may inflict more damage to the tissue and hence obtaining the quickest clinical and hematological improvements. Nevertheless, dexamethasone should be used with caution due to the hazards of its immunosuppressive effect on the host by putting the treated animals under careful observation (22 and 23). 
Table,1:Clinical signs in sheep affected with fascioliasis pre and post treatment

\begin{tabular}{|c|c|c|c|c|c|}
\hline \multirow[t]{3}{*}{ Clinical signs } & \multirow{3}{*}{$\begin{array}{c}\text { Pretreatment week } \\
\text { No. of animals } \\
\text { affected }\end{array}$} & \multicolumn{4}{|c|}{ Weeks Post treatment } \\
\hline & & \multicolumn{2}{|c|}{$1^{\text {st }}$ group } & \multicolumn{2}{|c|}{$2^{\text {nd }}$ groups } \\
\hline & & W1 & W2 & W1 & W2 \\
\hline Pale mucous membrane & 22 & 12 & 5 & 10 & $\mathbf{0}$ \\
\hline Weakness and emaciation & 19 & 11 & 4 & 8 & $\mathbf{0}$ \\
\hline Decreased appetite & 13 & 9 & 2 & 4 & $\mathbf{0}$ \\
\hline Loss and brittle wool & 15 & 7 & 4 & 8 & $\mathbf{0}$ \\
\hline Bottle jaw & 7 & 4 & 3 & 3 & $\mathbf{0}$ \\
\hline Jaundice & 6 & 4 & 3 & 2 & $\mathbf{0}$ \\
\hline Percentage $\%$ of weight gain & 46 & 41 & 4.9 & 5 & $6.9 *$ \\
\hline
\end{tabular}

* $(\mathbf{P}<0.05) \quad$ W1: $1^{\text {st }}$ week $\quad$ W2 : $2^{\text {nd }}$ week

Table,2:Hematological, biochemical and fecal egg count in sheep pre and post treatment with triclabedazole and dexamethasone.

\begin{tabular}{|c|c|c|c|c|c|}
\hline \multirow[t]{3}{*}{ Parameter } & \multirow[t]{3}{*}{ Pretreatment } & \multicolumn{4}{|c|}{ Weeks post treatment } \\
\hline & & \multicolumn{2}{|l|}{$1^{\text {st }}$ group } & \multicolumn{2}{|l|}{$2^{\text {nd }}$ groups } \\
\hline & & W1 & W2 & W1 & W2 \\
\hline RBCs count $10^{6} \mathrm{cmm}$ & $5.22 \pm 0.2$ & $5.6 \pm 0.3$ & $5.9 \pm 0.9$ & $6.2 \pm 0.2$ & $7.9 \pm 0.4$ \\
\hline Hb gm/dl & $6.9 \pm 3.1$ & $7.3 \pm 0.4$ & $7.8 \pm 0.5$ & $7.2 \pm 2.9$ & $9.2 \pm 0.7$ \\
\hline PCV \% & $30.4 \pm 8.2$ & $32.4 \pm 6.7$ & $32.8 \pm 7.1$ & $34.9 \pm 5.2$ & $38.9 \pm 6.2$ \\
\hline $\begin{array}{l}\text { Eosinophil count } \\
(\mathrm{cmm})\end{array}$ & $6.30 \pm 8.9$ & $250 \pm 13.2 *$ & $200 \pm 18.4 *$ & $105 \pm 6.6 * *$ & $95 \pm 2.8 * *$ \\
\hline Fibrinogen gm/dl & $206 \pm 9.2$ & $256 \pm 6.8 *$ & $366 \pm 16.1 *$ & $495 \pm 8.4$ & $496 \pm 7.6$ \\
\hline SGOT (IU/L) & $144.2 \pm 8.9$ & $110 \pm 6.5$ & $90.6 \pm 9.9$ & $80 \pm 6.3$ & $65.3 \pm 7.1 *$ \\
\hline SGPT (IU/L) & $55.6 \pm 6$ & $55.4 \pm 6.1$ & $45.3 \pm 6.6$ & $44.3 \pm 2.8$ & $55.3 \pm 4.7$ \\
\hline SAPT (IU/L) & $26.7 \pm 6.7$ & $20.2 \pm 7.2$ & $19.6 \pm 3.4$ & $17.1 \pm 3.3$ & $13.6 \pm 5.2$ \\
\hline SLDH (IU/L) & $275.2 \pm$ & $207.5 \pm 16.1$ & $200 \pm 7.1$ & $170 \pm 6.2$ & $141.3 \pm 6.7$ \\
\hline Albumin (gm/dl) & $3.3 \pm 0.6$ & $3.8 \pm 2.1$ & $5.1 \pm 3.3^{*}$ & $5.2 \pm 2.1 *$ & $7.9 \pm 2.2 * *$ \\
\hline Glucose (mg/dl) & $65.6 \pm$ & $68.7 \pm 0.8$ & $76.1 \pm 0.3$ & $89.5 \pm 30 *$ & $101.6 \pm 2.9 * *$ \\
\hline Cholesterol (mg/dl) & 99.8 \pm & $99.8 \pm 6.2$ & $106.3 \pm 7.1$ & $111.6 \pm 5.8$ & $116.2 \pm 2.8$ \\
\hline Bilirubin (gm/dl) & $0.91 \pm 0.2$ & $0.89 \pm 0.6$ & $0.72 \pm 0.2$ & $0.67 \pm 0.1$ & $0.31 \pm 0.02 *$ \\
\hline $\begin{array}{l}\text { Fecal egg count } \\
\text { (e.p.g) }\end{array}$ & $35.6 \pm 2.900 .0$ & 00.00 & 00.00 & 00.00 & 00.00 \\
\hline
\end{tabular}

$*(\mathbf{P}<0.05) \quad * *(\mathbf{P}<0.01) \quad \mathbf{W}:$ week

\section{References}

1. Abdul-Rhaman, R.A. (1978). Studies on some aspects of ovine fascioliasis in Iraq. MSc Thesis, College of Veterinary Medicine, University of Baghdad, Iraq.

2. Khalil, F.J.; Kawan, M.H. and Aboaud, H.B. (2008). Clinical, hematological and biochemical pictures as a monitor of caprine fascioliasis AL-Tagani, J, Agricul. Res., 21(2):1-6.

3. Rhadostits, O.M.; Blood, D.C. and Gay, C.C. (2000). Textbook of Veterinary Medicine, Dously, USA., PP:1230-1235.

4. Altaif, K.I. (1970). Observation on the incidence and seasonal variation on some eggs and larvae of helminthes in sheep. Bull. End. Dis., 12:99-104.

5. Dahri, A.; Taha, S.A. and Avadsian ,G.A. (1979). Prevalence hydatidiosis and fascioliasis in Iraq. The Veterinarian, 7(1):23-28.

6. Awad, A.H. and Al-Aziz, S.A. (1999). Survey on Fasciola gigantica in slaughtered animals in Basrah Abittoir. J. Basrah Vet. Res., 24(1):45-53.

7. Ali, S.S. (1988). A study on the effect of Fasciola gigantica in sheep and goat in Iraq. MSc Thesis, College of Veterinary Medicine, University of Baghdad. 
8. Petalia, T.M.(2000). Chronic fascioliasis is the most common clinical syndrome associated with liver fluke infection in sheep and cattle.http://www.Petalia.com.an /templates/storytemplate processes.cfm.

9. Plunb, D.C. (1999). Veterinary drug and book, $3^{\text {rd }} \mathrm{Ed}$. Iowa state University press, Ames, USA. PP: 76-80.

10. Farag, H. (2001). Human fascioliasis in some countries of Middle Eastren region. Office of WHO 22 May http://www.emro.whoint/publications/emly /0401/24htm.

11. Bowman, D.D. (2008). Georg's Parasitology for Veterinarians, $9^{\text {th }}$ ed Saunder's Elsivier, Missouri. USA. PP: 5563.

12. Blanca, E. ; Dumenigo, R. ; Carlos, M. and Finlay, V. (2000). Anemia of ovine Fascioliasis. Rev. Cubana. Med. Trop., 50(3):209-214.

13. Mezo, M.; Gonzales, N.; Warleta, M. and Ubieria, F.M. (2003). Optimized sero diagnosis of sheep fascioliasis by Fast-D Protein liquid chromatography fractionation of Fasciola hepatica exceretory-secretory antigens. J. Parasitol., 89(4):843-849.

14. Colse, E. (1978). Veterinary clinical pathology $3^{\text {rd }}$ ed . Iowa state University press, USA, PP: 410-428.

15. Benjamine, M.M. (1978). Outline of Veterinary Clinical Pathology $3^{\text {rd }}$ ed. Iowa state University press, Ames USA., PP:122-128.

16. SAS, Institute, I. (2001). Statically Analysis's system Institute Inc.Cary,N.C; USA.

17. Baker, D.W. (1970). Liver Fluke Disease. In Bovine Medicine and Surgery $1^{\text {st }}$ ed. by H.E. Amstut. Am. Vet. Publication, Santa Darbara, PP: 67-70.

18. Jubb, K.V.; Kennedy, P.C. and Palmer, N. (1994). Pathology of domestic animals. $4^{\text {th }}$ ed., Academic press, San Diego, New York, USA. PP: 53-58.

19. Kahn, C.M. (2005). The Merck Veterinary Manual $9^{\text {th }}$ ed. A. Merck and Aventis Co.,USA., PP:223-230.

20. Rhayma, M.H. (1994). Ovine fascioliasis: Clinical, hematological and biochemical study. Iraqi. J. Vet. Sci., 7:37-41.

21. Khalil, F.J. (1997). Effect of tricloabendazole on a natural infection of goats with Fasciola gigantica. The Veterinarian (Iraq), (6,7)1:35-39.

22. Adama, U.Y.; Ajamusi, O.J.; Chionzey, N. and Lawal, A. (2011). Biochemical response of yankasa sheep to experimental Fasciola gigantica infection in Nigeria. Int. J. Anim. and Vet. Adv., 3(6):409-415.

23. John, D.T. and Petri, W.A. (2008). Markell and Voges medical parsitology, $9^{\text {th }}$ ed. Saundrs and Elsevier, Missouri, USA, PP: 276-280

$$
\begin{aligned}
& \text { تاثثير عقاري التر اكلابندازول و الدكساميثازون على الاصنابة بديدان الكبد في الاغنام }
\end{aligned}
$$

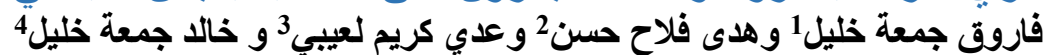

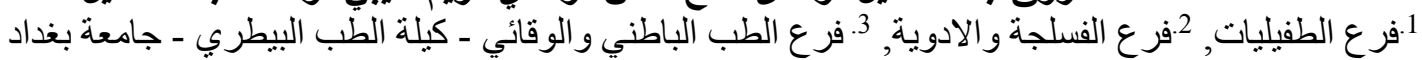

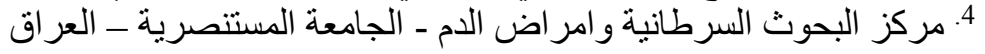

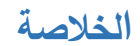

اختير ثلاثون راس من الغنم تعاني من اعر اض ديدان الكبد لاجر اء التجربة اذ اجري الفحص السريري وفحوصات الدمية

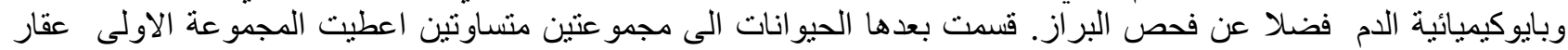

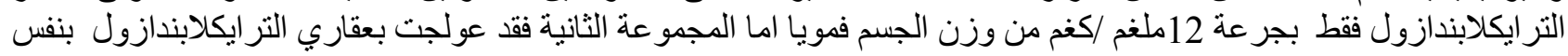

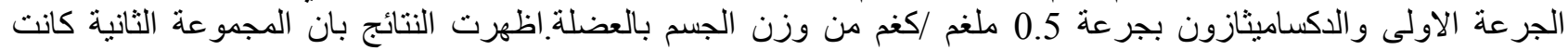

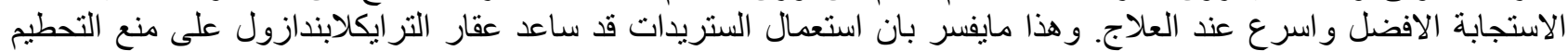
المناعي للانسجة وايقاف عملية التليف الحاصل في الكبد فضلا عن التحسن في الفعاليات الايضية للحيو التئران .

$$
\text { الكلمات المفتاحية : التراكلابندازول , الدكساميثازون , ديدان الكبد , الاغنام. }
$$

